\title{
PENGGUNAAN KAYU MANIS (Cinnamomum burmani) UNTUK MENGATASI KETENGIKAN PADA MINYAK KELAPA SECARA TRADISIONAL
}

\author{
Kadir, Shabri Putra Wirman, Sri Fitria Retnowaty, Aji Suroso \\ Program Studi Fisika, Fakultas MIPA dan Kesehatan \\ Univeristas Muhammadiyah Riau
}

\begin{abstract}
Coconut oil is an oil produced from coconuts. Based on the high levels of saturated fatty acids and lauric acid (anti-microbial) makes coconut oil as an oil that has the highest quality of other oils. But if oil is stored in a long time it will cause rancidity. Rancidity can be caused by several factors such as oxidation and hydrolysis reactions. One way to overcome this is to add antioxidant rancidity. Antioxidants can be found in everyday life, such as the onion, cloves, betel leaf and cinnamon. In this study using cinnamon oil as an antioxidant and $\mathrm{pH}$ were tested for physical parameters such as viscosity, Density, conductivity, resistivity, and the smell test. The results of the $\mathrm{pH}$ test and demonstrate physical if cinnamon can prevent oil from rancidity based on the length of storage. And the addition of cinnamon to a maximum of 8 grams are in 50 $\mathrm{ml}$ of coconut oil has a $\mathrm{pH}$ value, Viscosity, Density, conductivity, resistivity, and the test odors better than the other samples.
\end{abstract}

Key Word: Coconut Oil, Antioxidants, Cinnamon, pH Test, Physical Test.

\section{PENDAHULUAN}

Indonesia adalah negara yang memiliki hasil alam yang melimpah. Banyak diantaranya yang menjadi komoditi ekspor, salah satunya adalah tanaman kelapa. Kelapa tumbuh hampir di seluruh kepulauan nusantara, sehingga Indonesia mendapat peringkat pertama dalam area tanaman kelapa terluas di dunia yaitu mencapai 3,90 juta hektar. Hampir seluruh bagian tanaman ini bermanfaat bagi kehidupan manusia sehingga tanaman kelapa disebut juga sebagai pohon kehidupan. Salah satu hasil dari olahan kelapa saat ini yang banyak dipakai dalam bidang industri adalah minyak kelapa, minyak murni, santan, nata de coco, tepung, cuka, karbon aktif, serat sabut dan industri pemanfaatan batang kelapa [1].

Minyak kelapa adalah minyak yang dihasilkan dari buah kelapa. Berdasarkan pada tingginya kadar asam lemak jenuh dan asam laurat (anti mikroba) pada minyak kelapa menjadikan minyak kelapa sebagai minyak yang memiliki mutu tertinggi dari minyak lainnya. Minyak kelapa memiliki manfaat yang sangat penting bagi tubuh kita terutama dalam proses metabolisme karena pada minyak kelapa banyak mengandung vitamin A, D, E dan K serta Provitamin A (karoten) yang mudah larut dalam lemak. Selain itu minyak kelapa juga sangat bermanfaat bagi penderita penyakit kronis seperti penyakit jantung dan Human Immunodeficiency Virus (HIV) [2, 3].

Namun jika minyak kelapa disimpan dalam waktu yang lama maka akan menimbulkan ketengikan. Proses ketengikan (rancidity) pada minyak kelapa menyebabkan timbulnya bau dan rasa tengik. Ketengikan dapat mengakibatkan menurunnya nilai gizi pada minyak kelapa. Ketengikan dapat diakibatkan oleh beberapa reaksi seperti reaksi oksidasi dan reaksi hidrolisis. Salah satu cara mengatasi ketengikan adalah dengan menambahkan antioksidan. Antioksidan itu sendiri dapat diartikan sebagai senyawa yang dapat menunda, memperlambat dan mencegah terjadinya oksidasi lipid pada minyak kelapa. Antioksidan dapat kita temukan dalam kehidupan sehari-hari, salah satunya adalah antioksidan pada bawang merah, cengkeh, daun sirih dan kayu manis [4]. 
Beberapa penelitian yang sudah dilakukan untuk mengatasi ketengikan pada minyak kelapa diantaranya adalah penelitian yang dilakukan oleh Nana Dyah Siswantin, Juni SU dan Junaini yang mengatasi ketengikan minyak kelapa dengan menggunakan ekstrak kulit bawang merah yang mengandung antioksidan alami. Serta penelitian lain dalam mengatasi ketengikan minyak kelapa adalah penelitian oleh Fahrurizal Litupa dan Hismi Susane, dimana dengan jumlah minyak cengkeh yang lebih banyak mampu mengatasi ketengikan pada minyak kelapa $[4,5]$.

Merujuk pada beberapa penelitian di atas penulis mencoba menggunakan antioksidan yang terkandung di dalam kayu manis untuk mengatasi ketengikan pada minyak kelapa dengan menguji karakteristik fisis dan $\mathrm{pH}$ dari minyak kelapa.

\section{METODOLOGI PENELITIAN}

Alat

Alat yang digunakan dalam penelitian ini terdapat dua tahap, diantaranya;

1. Tahap pembuatan minyak kelapa diantaranya seperangkat peralatan dapur, parutan kelapa, saringan, dan botol.

2. Tahap pengujian, diantaranya satu set portable $\mathrm{pH}$, TDS, ORP, Conductivity meter. Satu set tabung viskometer ostwald, stopwatch, Gelas ukur, Neraca Digital dan pipet tetes.

\section{Bahan}

Bahan yang digunakan dalam penelitian ini yaitu 50 buah kelapa tua dan 5 liter air serta kayu manis.

\section{Prosedur Kerja}

Kelapa sebanyak 50 buah diambil dagingnya untuk diparut kemudian ditambahkan air lalu diperas hingga mengeluarkan santan. Santan yang dihasilkan dari 50 buah kelapa yaitu sebanyak 16 $\mathrm{kg}$. Kemudian santan dipanaskan hingga menguap dan tinggal padatan yang menggumpal. Gumpalan padatan itu disebut blondo. Kemudian pisahkan antara minyak dan blondo dengan cara penyaringan. Jumlah minyak kelapa dari proses penyaringan tersebut yaitu sebanyak $2000 \mathrm{ml}$. Setelah minyak dan blondo terpisah, memasukkan minyak kelapa ke dalam lima botol yang berbeda.
Dengan beberapa variasi sampel, diantaranya: Sampel A berisi $50 \mathrm{ml}$ minyak minyak kelapa.

a. Sampel B berisi $50 \mathrm{ml}$ minyak kelapa ditambah 2 gram kayu manis utuh.

b. Sampel $\mathrm{C}$ berisi $50 \mathrm{ml}$ minyak kelapa ditambah 4 gram kayu manis utuh.

c. Sampel $\mathrm{D}$ berisi $50 \mathrm{ml}$ minyak kelapa ditambah 6 gram kayu manis utuh.

d. Sampel E berisi $50 \mathrm{ml}$ minyak kelapa ditambah 8 gram kayu manis utuh.

Metodelogi dalam penelitian ini ditunjukkan pada Gambar 1.

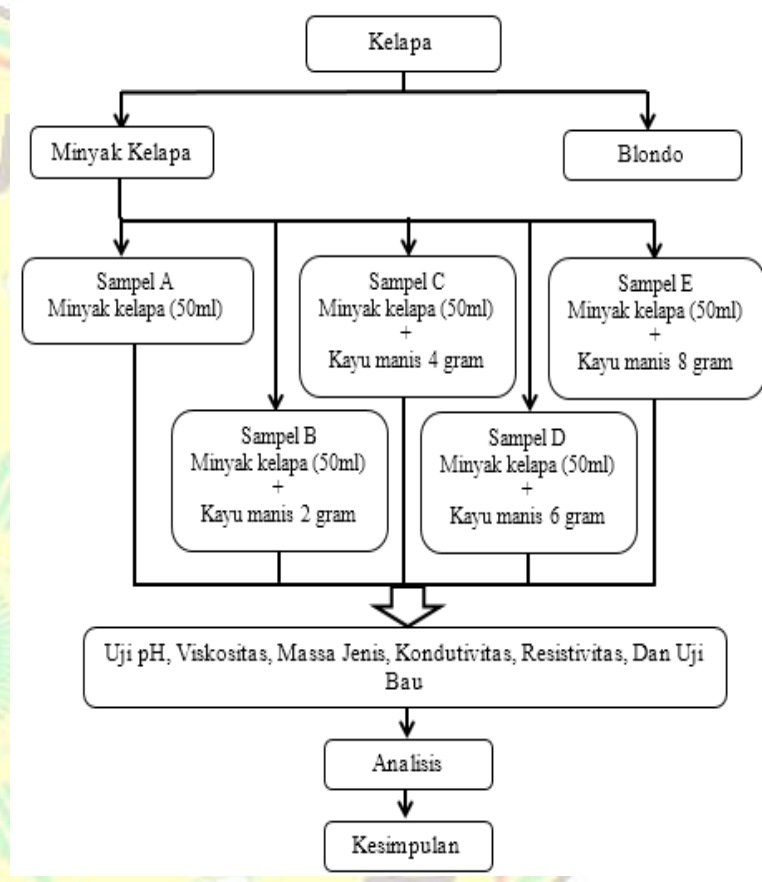

Gambar. 1. Diagram Alir Penelitian

\section{Uji pH}

Uji pH dilakukan dengan menggunakan alat pH meter. Caranya yaitu dengan memasukkan alat pH meter ke dalam minyak kelapa dan membaca nilai $\mathrm{pH}$ pada layar $\mathrm{pH}$ meter. Kemudian mengulangi langkah tersebut sebanyak 3 kali. Pada setiap pengulangan pada ujung alat pendeteksi dibersihkan dengan aquadest.

\section{Uji Viskositas}

Uji viskositas dilakukan dengan cara memasukkan minyak kelapa ke dalam viskometer ostwald hingga pada garis batas yang terdapat pada viskometer tersebut. Selajutnya pasang alat penarik udara (bulb) pada ujung atas lubang viskometer. Setelah itu penarik udara ditekan dan mencatat waktu lamanya minyak kelapa turun 
hingga mencapai garis batas bawah yang terdapat pada viskometer.

Selanjutnya aquadest digunakan sebagai pembanding, yaitu dengan mencari waktu lamanya turun pada viskometer ostwald. Langkah tersebut diulangi sebanyak 3 kali. Kemudian diambil rata-rata waktu dari minyak dan air, kemudian menghitung nilai viskositas dengan Persamaan 2.1.

$$
\frac{\eta_{1}}{\eta_{2}}=\frac{T_{1}}{T_{2}} \frac{\rho_{1}}{\rho_{2}}
$$

Dengan $\eta_{1}$ adalam nilai viskositas minyak kelapa yang ingin dicari dan $\eta_{2}$ adalah nilai viskositas dari cairan pembanding yaitu aquadest. Kemudian untuk $\rho_{1}$ merupakan massa jenis dari minyak kelapa dan $\rho_{2}$ adalah massa jenis dari aquadest. Selanjutnya $T_{1}$ yang merupakan waktu yang dibutuhkan minyak kelapa untuk turun dari kapiler pada viskometer ostwald dan $T_{2}$ adalah waktu dari aquadest.

\section{Uji Massa Jenis}

Pada uji massa jenis minyak kelapa dimasukkan ke dalam gelas ukur sebanyak $25 \mathrm{ml}$. Kemudian timbang massa dari minyak tersebut. Hasil dari timbangan tersebut dikurangi dengan massa gelas ukur yang sudah diketahui sebelumnya untuk mendapatkan massa minyak kelapa. Setelah itu hitung perbandingan antara massa dan volume dari minyak tersebut dengan Persamaan 2.2. Langkah tersebut diulangi sebanyak 3 kali.

$$
\rho=\frac{m}{v}
$$

\section{Uji Konduktivitas}

Uji konduktivitas juga dilakukan dengan menggunakan alah conductivity meter. Caranya yaitu dengan memasukkan alat conductivity meter ke dalam minyak kelapa dan membaca nilai conductivity pada layar conductivity meter. Kemudian mengulangi langkah tersebuut sebanyak 3 kali. Pada setiap pengulangan pada ujung alat pendeteksi dibersihkan dengan aquadest.

\section{Uji Resistivitas}

Uji resistivitas dilakukan dengan menggunakan alat resistivity meter. Caranya yaitu dengan memasukkan alat resistivity meter ke dalam minyak kelapa dan membaca nilai resistivity pada layar resistivity meter. Kemudian mengulangi langkah tersebuut sebanyak 3 kali.

\section{Uji Bau}

Uji bau dilakukan oleh 10 panelis tak terlatih dengan jenis kelamin yang berbeda. Jenis kelamin tersebut yaitu 6 wanita dan 4 pria dewasa dengan usia berada pada rentang 25-35 tahun. Kemudian para panelis akan membrikan penilaian terhadap aroma dari minyak kelapa tersebut. Penilaian yang diberikan yaitu 1 = bau dan $2=$ tidak bau. Uji bau dilakukan selama 8 minggu untuk semua sampel minyak kelapa.

\section{HASIL DAN PEMBAHASAN}

Penelitian yang telah dilakukan terhadap minyak kelapa dengan penambahan kayu manis sebagai antioksidan dengan parameter yang diuji meliputi pH, Viskositas, Massa Jenis, Kondutivitas, Resistivitas, dan Bau yang menghasilkan data sebagai berikut.

\section{pH}

Pada Gambar 2 nilai pH pada semua sampel berbeda-beda. Pada gambar tersebut terlihat jika pada minggu pertama nilai $\mathrm{pH}$ dari sampel A hingga E memiliki nilai yang bervariasi. Dan nilai $\mathrm{pH}$ tertinggi diminggu pertama terdapat pada sampel A.

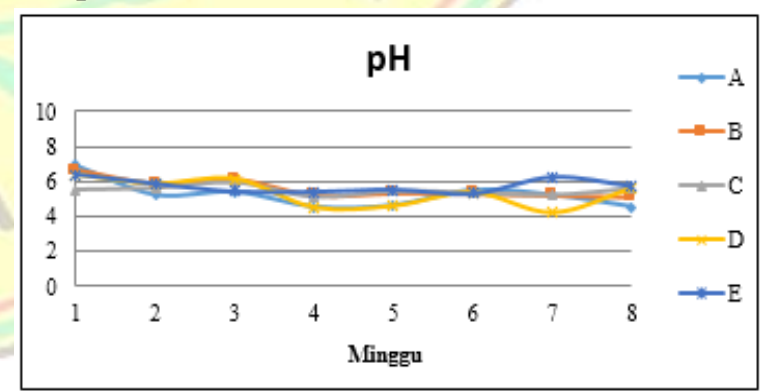

Gambar. 2. Hubungan nilai $\mathrm{pH}$ minyak kelapa terhadap lamanya penyimpanan

Nilai pH pada semua sampel tersebut menurun pada minggu ke-dua dari minggu pertama. Pada minggu berikutnya untuk sampel A, $\mathrm{B}, \mathrm{C}$ dan E naik diminggu ke-tiga dan cenderung stabil hingga minggu ke-tujuh.

Kemudian untuk nilai $\mathrm{pH}$ sampel A menurun diminggu ke-delapan dan stabil untuk sampel B 
dan C. Hal tersebut dapat disebabkan karena adanya perbedaan suhu pada saat pengambilan nilai $\mathrm{pH}$. Sehingga dengan hal tersebut nilai $\mathrm{pH}$ pada sampel A menurun.

Hasil yang berbeda ditunjukkan pada sampel $\mathrm{D}$, dimana sampel tersebut memiliki nilai $\mathrm{pH}$ yang lebih rendah dibandingkan yang lain. Dari minggu pertama nilai $\mathrm{pH}$ pada sampel $\mathrm{D}$ menurun hingga minggu ke-empat, dan naik di-mingggu ke-lima hingga minggu ke-enam. Minggu ke-tujuh nilai pH sampel D menurun dan naik pada minggu kedepalan.

Selain sampel D nilai pH pada sampel E juga menunjukkan perbedaan dibandingkan dengan sampel lainnya. Nilai $\mathrm{pH}$ pada sampel $\mathrm{E}$ cenderung stabil hingga minggu ke-enam dan naik diminggu ke-tujuh dan turun pada minggu kedelapan.

Naiknya nilai $\mathrm{pH}$ sampel E diminggu ketujuh dapat disebabkan karena perbedaan suhu pada saat pengambilan. Dimana pada saat pengambilan nilai $\mathrm{pH}$ sampel $\mathrm{E}$ suhu terbaca adalah $30,3^{\circ} \mathrm{C}$. Suhu tersebut lebih tinggi dibandingkan dengan suhu pada sampel lainnya diminggu ke-tujuh.

Berdasarkan nilai $\mathrm{pH}$ pada sampel $\mathrm{E}$ tersebut menunjukkan jika dengan penambahan kayu manis dengan jumlah yang banyak dapat menghindari minyak kelapa dari ketengikan. Perbedaan nilai $\mathrm{pH}$ pada sampel minyak kelapa dapat disebabkan karena proses oksidasi pada setiap sampel berbeda-beda. Dimana proses oksidasi tersebut dapat dipengaruhi oleh jumlah penambahan kayu manis [5].

Naik dan turunnya nilai $\mathrm{pH}$ tersebut dapat disebabkan karena proses oksidasi dari minyak kelapa tersebut. Dimana molekul-molekul lemak pada minyak kelapa yang mengandung radikal asam lemak tidak jenuh akan mengalami oksidasi yang dapat menimbulkan bau tengik. Dan proses oksidasi tersebut dipengaruhi oleh suhu yang berbeda. Dengan terjadinya proses oksidasi tersebut menyebabkan minyak menjadi asam dan nilai $\mathrm{pH}$ semakin menurun. Nilai $\mathrm{pH}$ yang menurun menandakan jika minyak kelapa semakin asam. [5, 6].

\section{Viskositas}

Pada Gambar 3 dapat dilihat jika pada semua sampel mengalami perubahan untuk setiap minggunya. Diminggu pertama nilai viskositas untuk semua sampel cenderung sama, hanya terdapat sedikit perbedaan untuk setiap sampelnya. Kemudian pada minggu ke-dua nilai viskositas cenderung naik signifikan untuk semua sampel. Selanjutnya diminggu ke-tiga nilai viskositas menurun kembali hingga minggu terakhir.

Sampel A menunjukan jika nilai viskositas tersebut cenderung menurun. kemudian hal yang sama juga ditunjukkan pada data sampel B, C , D dan E. Dimana dari minggu pertama dan ke-dua naik signifikan, kemudian turun sigifikan pada minggu ke-tiga dan menurun cenderung stabil pada minggu berikutnya. Sehingga ke-lima sampel tersebut menunjukkan nilai yang cenderung menurun.

Akan tetapi diminggu ke-tujuh terjadi penurunan nilai viskositas yang signifikan pada sampel D dan E. Dimana ke-dua sampel tersebut memiliki nilai viskositas yang sangat rendah dibandingkan dengan sampel lainnya. Hal tersebut dapat disebabkan karena perbedaan suhu pada saat pengambilan nilai viskositas. Suhu untuk sampel D dan E pada saat pengambilan diminggu ke-tujuh yaitu $30^{\circ} \mathrm{C}$. Dan suhu tersebut lebih tinggi dibandingkan dengan sampel lainnya.

Kemudian pada minggu ke-delapan nilai viskositas pada semua sampel menurun. hal tersebut diikuti leh suhu pada saat pengambilan nilai viskositas yang naik yaitu $31{ }^{\circ} \mathrm{C}$ hingga $31,5^{\circ} \mathrm{C}$. Sehingga menurunnya nilai viskositas yang disebabkan oleh suhu menandakan jika kayu manis tidak mempengaruhi nilai viskositas pada sampel minyak kelapa.

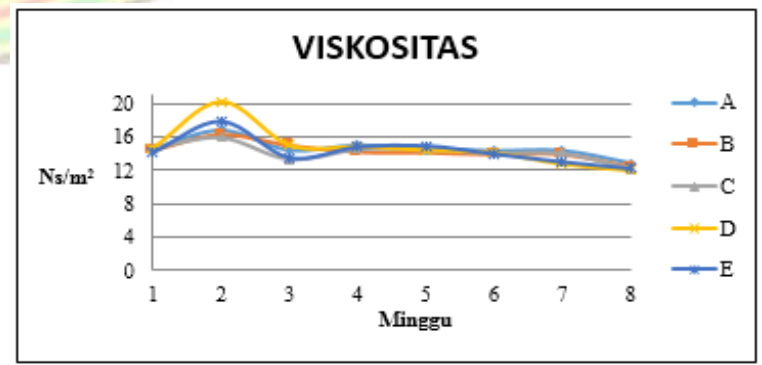

Gambar. 3. Hubungan nilai viskositas minyak kelapa terhadap lamanya penyimpanan 
Dengan demikian penambahan kayu manis tidak memberikan pengaruh terhadap nilai viskositas minyak kelapa. Hal tersebut dikarenakan naik dan turunnya nilai viskositas dipengaruhi oleh tinggi dan rendahnya suhu.

Perbedaan suhu pada saat pengambilan data viskositas minyak kelapa menyebabkan nilai viskositas menurun. Selain itu minyak kelapa yang dipakai dalam penelitian ini adalah minyak kelapa yang baru dibuat (dihasilkan). Dimana minyak kelapa baru yang belum pernah dipakai memiliki nilai viskositas yang cukup besar. Dan nilai tersebut akan menurun berdasarkan lamanya penyimpanan dengan perubahan temperatur yang ada $[7,8]$.

\section{Massa Jenis}

Gambar 4 merupakan hasil dari massa jenis minyak kelapa dengan penambahan kayu manis dan lamanya penyimpanan. Berdasarkan gambar tersebut nilai massa jenis pada semua sampel tidak mengalami perubahan yang cukup jauh.

Hal tersebut dapat dilihat pada minggu pertama dimana untuk setiap sampel memiliki nilai massa jenis yang tidak terlalu jauh berbeda. Hal yang sama juga terjadi diminggu ke-dua hingga minggu terakhir pengambilan nilai massa jenis pada sampel minyak kelapa. Nilai pada semua sampel minyak tersebut tetap, yaitu berkisar antara $895 \mathrm{~g} / \mathrm{cm}^{3}-900 \mathrm{~g} / \mathrm{cm}^{3}$.

Nilai massa jenis untuk semua sampel cenderung sama pada setiap pengambilan. Samanya kecenderungan nilai massa jenis dari minyak kelapa tersebut, dapat disebabkan karena minyak yang digunakan adalah minyak kelapa yang baru (belum pernah digunakan). Minyak kelapa yang baru memiliki nilai massa jenis yang besar, dan akan menurun jika telah digunakan (dipanaskan). Sehingga nilai massa jenis tidak akan mudah berubah dengan adanya perubahan temperatur yang kecil. Dan dari hasil penelitian berdasarkan lama waktu penyimpanan dapat dilihat bahwa, kayu manis tidak mempengaruhi nilai massa jenis dari minyak kelapa [8].

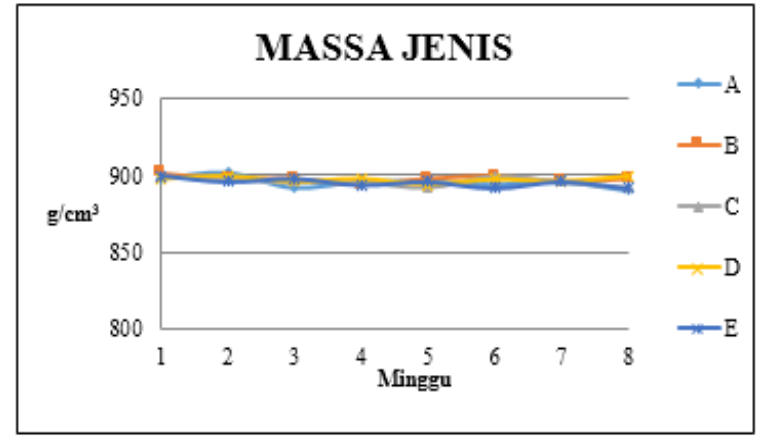

Gambar. 4. Hubungan nilai massa jenis minyak kelapa terhadap lamanya penyimpanan

\section{Konduktivitas}

Gambar 5 merupakan hasil dari nilai konduktivitas minyak kelapa dengan sampel yang berbeda. Pada Gambar terlihat jika sampel B dan D menurun secara signifikan dari minggu pertama hingga ke-dua. Untuk sampel B naik signifikan pada minggu ke-tiga dan menurun signifikan diminggu ke-lima kemudian cenderung stabil pada minggu berikutnya.

Sedangkan untuk sampel D naik stabil pada minggu ke-tiga kemudian naik secara signifikan pada minggu ke-empat dan menurun signifikan diminggu ke-lima serta cenderung stabil pada minggu berikutnya hingga minggu terakhir.

Pada sampel A dan E nilai konduktivitas cenderung menurun stabil diminggu ke-dua. Kemudian sampel A naik signifikan diminggu ketiga dan ke-empat. Setelah itu sampel A menurun signifikan pada minggu ke-lima dan cenderung stabil diminggu selanjutnya hingga minggu terakhir. Berbeda dengan sampel A, sampel E menurun stabil hingga minggu ke-tiga, kemudian naik diminggu ke-lima dan cenderung stabil diminggu berikutnya. Untuk sampel $\mathrm{C}$ dari minggu pertama hingga ke-empat cenderung menurun stabil dan menurun signifikan pada minggu ke-lima, kemudian cenderung stabil pada minggu berikutnya hingga minggu terakhir.

Menurunnya nilai konduktivitas yang ditunjukkan pada semua sampel dari minggu ke lima hingga ke delapan. Menurunnya nilai tersebut dapat disebabkan oleh adanya perubahan suhu. Dimana ketika suhu naik, maka nilai konduktivitas suatu cairan juga naik [9].

Dan pada saat nilai konduktivitas menunjukkan nilai 0 , suhu pada pengambilan tersebut menurun yaitu $28^{\circ} \mathrm{C}$. Dimana suhu pada 
pengambilan sebelumnya yaitu $29-31^{\circ} \mathrm{C}$. Selain faktor suhu di atas, faktor lain yaitu karena penambahan kayu manis pada minyak kelapa. Dimana dalam kayu manis terdapat kandungan minyak atsiri yang menguap pada suhu biasa (suhu kamar).

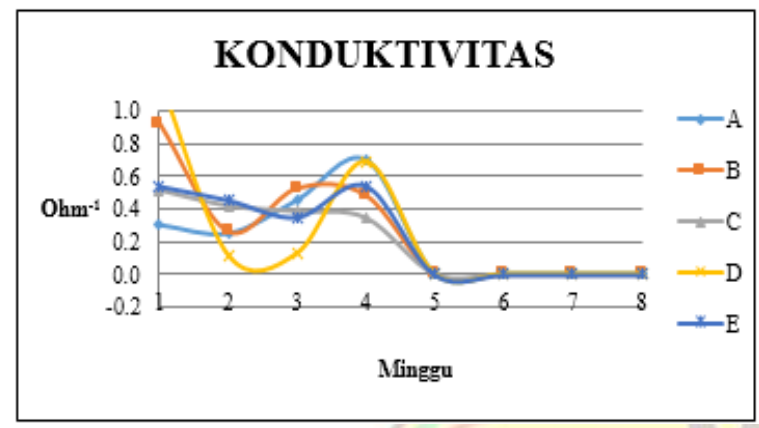

Gambar. 5. Hubungan nilai konduktivitas minyak kelapa terhadap lamanya penyimpanan

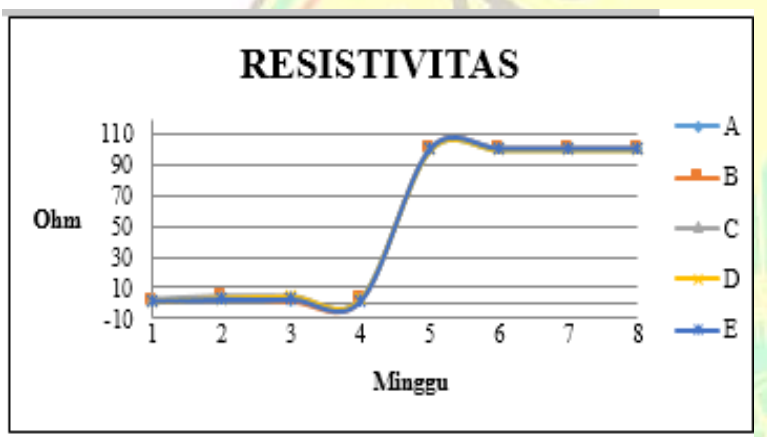

Gambar. 6. Hubungan nilai resistivitas minyak kelapa terhadap lamanya penyimpanan

Sehingga pada minggu awal mendapat suhu tambahan dari proses penguapan minyak atsiri tersebut. Maka dari itu pada minggu pertama hingga ke empat kandungan konduktivitas tinggi [10].

\section{Resistivitas}

Gambar 6 di atas menunjukkan hasil dari nilai resisitivitas, dimana nilai tersebut berbanding terbalik dengan hasil dari nilai konduktivitas di atas. Pada mingggu pertama hingga ke-empat nilai resistivitas sampel $\mathrm{A}, \mathrm{B}, \mathrm{C}, \mathrm{D}$ dan $\mathrm{E}$ cenderung sama (tetap), kemudian naik signifikan pada minggu ke-lima dan cenderung stabil hingga minggu terakhir. Dimana nilai tersebut menunjukkan nilai 0 (nol) pada minggu pertama hingga ke empat. Dan kandungan nilai resistivitas terdapat pada minggu ke lima hingga ke delapan. Hasil yang ditunjukkan pada Gambar tersebut sesuai dengan nilai konduktivitas, yaitu jika nilai konduktivitas tinggi maka resistivitas akan rendah [11].

Dari ke-dua grafik resistivitas dan konduktivitas di atas menunjukkan, jika pada grafik hasil nilai resistivitas pada minggu pertama hingga ke empat adalah 0 (nol). Hasil yang berbeda ditunjukkan pada grafik hasil nilai konduktivitas, jika nilai konduktivitas terdapat pada minggu pertama hingga ke-empat

Dengan demikian teori yang ada sesuai dengan nilai konduktivitas dan resistivitas di atas. Faktor perbedaan nilai tersebut juga dapat dipengaruhi oleh faktor suhu. Kemudian selain faktor tersebut jumlah penambahan kayu manis juga menjadi salah satu faktor pengaruh nilai resistivitas $[8,9]$.

\section{Bau (Aroma)}

Gambar di bawah merupakan hasil dari uji bau dari minyak kelapa terhadap lamanya penyimpanan. ketengikan atau tidaknya dari minyak kelapa pada gambar tersebut ditunjukkan dengan angka 1 adalah "bau" dan untuk angka 2 yaitu "tidak bau". Pada gambar tersebut terlihat jika minyak kelapa pada minggu pertama dan kedua tidak mengalami ketengikan. Ketengikan atau bau mulai terdapat pada sampel A diminggu ketiga dan minggu berikutnya hingga minggu kedelapan (terakhir) (Gambar 7). Untuk sampel B ketengikan dimulai pada minggu ke-lima hingga minggu ke-delapan (Gambar 8).

Sampel C dan D ketengikan dimulai pada minggu ke-tujuh dan ke-delapan (Gambar 9 dan 10). Sedangkan untuk sampel $E$ tidak mengalami ketengikan hingga minggu terakhir (ke-delapan).

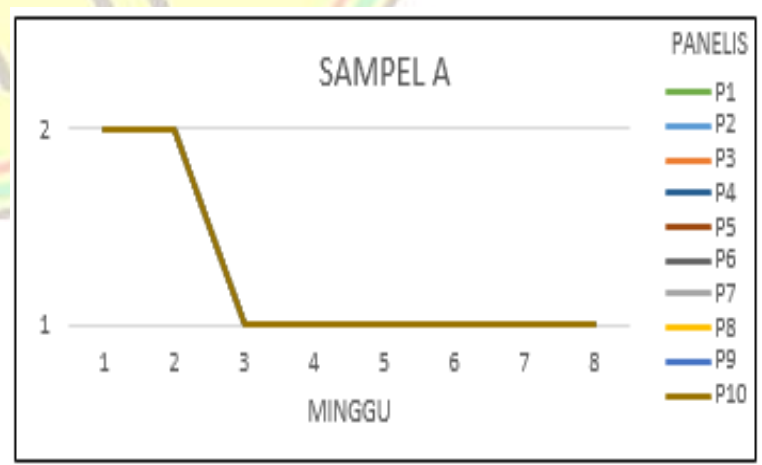

Gambar. 7. Hasil Uji Bau Sampel A 


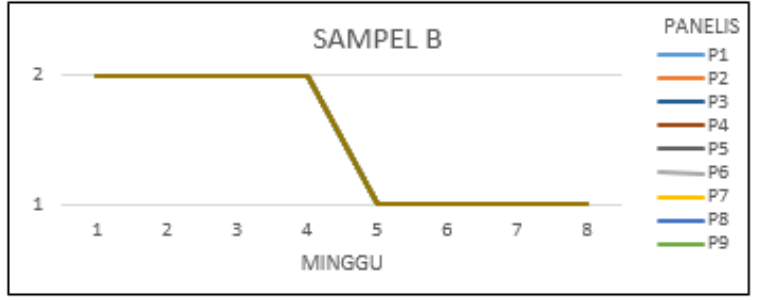

Gambar. 8. Hasil Uji Bau Sampel B

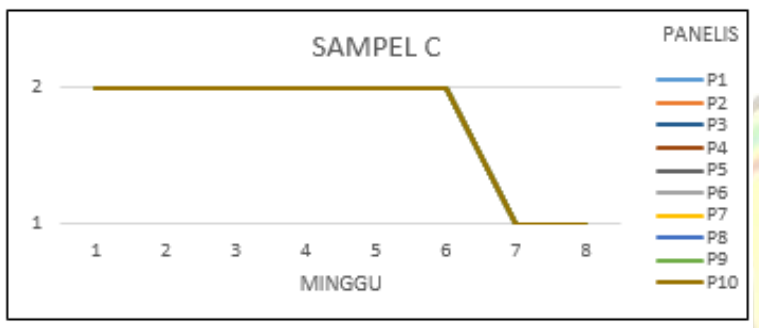

Gambar. 9. Hasil Uji Bau Sampel C

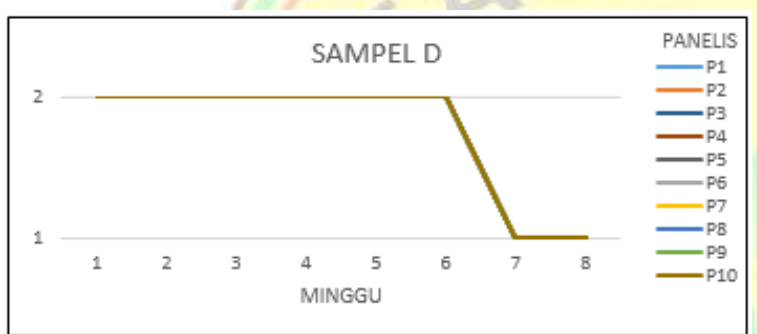

Gambar. 10. Hasil Uji Bau Sampel D



Gambar. 11. Hasil Uji Bau Sampel B

Dari tersebut dapat dilihat jika penambahan kayu manis dapat mengurangi ketengikan pada minyak kelapa. Dimana semakin banyak penambahan kayu manis, minyak kelapa mampu bertahan dari ketengikan hingga minggu terakhir penyimpanan (delapan).

Jumlah penambahan dari kayu manis pada minyak kelapa menjadi faktor terhindarnya minyak kelapa dari ketengikan. Karena semakin banyak kayu manis yang ditambahkan, maka akan semakin banyak kandungan minyak atsiri dan semakin banyak proses penguapan yang terjadi. Sehingga proses oksidasi berkurang dan menyebabkan minyak kelapa lebih awet (tahan lama) dari ketengikan [5,9]

\section{KESIMPULAN \\ Kesimpulan}

Berdasarkan hasil yang telah diperoleh, maka dapat diambil beberpa kesimpulan sebagai berikut.

1. Nilai $\mathrm{pH}$ pada sampel $\mathrm{E}$ lebih stabil dibandingkan dengan sampel lainnya. Sedangkan untuk sampel A, B, C dan D, terjadi perubahan berdasarkan lamanya penyimpanan. Sehingga penambahan kayu manis mempengaruhi nilai $\mathrm{pH}$ pada sampel minyak kelapa.

2. Perbedaan nilai viskositas pada semua sampel disebabkan oleh perbedaan suhu pada saat pengambilan. Dan nilai massa jenis untuk semua sampel cenderung sama hingga hari terakhir pengambilan. Dengan demikian penambahan kayu manis tidak memberikan pengaruh terhadap nilai viskositas dan massa jenis minyak kelapa.

3. Nilai konduktivitas hanya terdapat pada minggu pertama hingga ke-empat untuk semua sampel. Dengan demikian penambahan kayu manis hanya memberikan pengaruh nilai konduktivitas minyak kelapa hingga minggu ke-empat.

4. Nilai resistivitas hanya terdapat pada minggu kelima hingga kedelapan. Hal tersebut dikarenakan pada minggu pertama hingga keempat nilai konduktivitas besar dan diminggu kelima hingga kedelapan rendah.

5. Hasil yang diperoleh pada uji bau untuk semua sampel yaitu semakin banyak kayu manis yang ditambahkan, maka dapat mengurangi ketengikan pada minyak kelapa pada setiap penyimpanan.

6. Berdasarkan hasil dari uji $\mathrm{pH}$, konduktivitas, resistivitas dan uji bau maka penambahan kayu manis mampu mengurangi ketengikan pada minyak kelapa

\section{DAFTAR PUSTAKA}

Luntungan, Henkie Tumundo. 2008. Pelestarian Sumber Daya Genetik Kelapa Sebagai Komoditas Unggulan dalam Pengembangan Lahan Rawa Pasang Surut dan Lebak. Jurnal pengembangan inovasi pertanian I (4), 2008: 243-256. Hal. 234 
Dwiyuni, Maya. 2006. Kajian Sifat Fisiko Kimia Ekstraksi Minyak Kelapa Murni (Virgin Coconut Oil, Vco) dengan Metode Pembekuan Krim Santan. Bogor. Institut Pertanian Bogor. SkripsiNi Luh Putu Manik Widiyanti dan Ni Putu Ristiati. Analisa Kualitatif Bakteri Koliform Pada Depot Air Minum Isi Ulang Di Kota Singaraja Bali. Jurusan Pendidikan Biologi, FMIPA IKIP Negeri Singaraja. Bali.

Allorerung, David, Mahmud, Zainal dan Prastowo, Bambang. 2008. Peluang Kelapa Untuk Pengembangan Produk Kesehatan. Jurnal pengembangan inovasi pertanian I (4), 2008: 298-315. Hal 304

Siswati, Nana Dyah, SU, Juni, Junaini. 2009. Pemanfaatan Antioksidan Alami Flavonol untuk Mencegah Proses Ketengikan Minyak Kelapa. .

Laitupa, Fahrurizal dan Susane, Hismi. 2010. Pemanfaatan Eugenol dari Minyak Cengkeh untuk Mangatasi Ranciditas pada Minyak Kelapa. Surabaya. Universitas Diponegoro. Tesis.

Syahrurrozi. 2009. Penetapan Kadar Minyak Atsiri Dan Kadar Air Pada Kayu Manis Dengan Metode Destilasi. Medan. Tugas akhir. Universitas Sumatra Utara

Mariance, Rince. 2006. Karakteristik Fisik dan pH Sari Wortel. Bogor. Institut Pertanian Bogor. Skripsi.
Budianto, Anwar. 2008. Metode Penentuan Koefisien Kekentalan Zat Cair Dengan Menggunakan Regresi Linier Hukum Stokes. Seminar Nasional SDM Teknologi Muklir Yogyakarta, 25-26 Agustus 2008. ISSN 1978-0176.Budianto, Anwar. 2008. Metode Penentuan Koefisisen Kekentalan Zat Cair Dengan Menggunakan Regresi Linear Hukum Stokes. Seminar Nasional SDM Teknologi Nuklir Yogyakarta, 25-26 Agustus 2008. ISSN 1978-0176.

Sutiah, Firdausi K., Dan Setia Budi, Wahyu. 2008. Studi Kualitas Minyak kelapa Dengan Parameter Viskositas Dan Indeks Bias. Jurnal berkala fisika Vol.11. No.2, April 2008, Hal 53-58

Purwanto P dkk. Pengaruh Suhu Terhadap Konduktivitas Elektrolit Padat. Tangerang. Jurnal Sains materi Indonesia. Puslitbang Iptek Bahan (P3IB).

Rahma Siti. 2009. Pencitraan Dua Dimensi Data Resistivity Dan Induced Polarization Untuk Mendelineasi Deposit Emas Sistem Epithermal Di Daerah " $X$ ". Jakarta. Fakultas Matematka Dan Ilmu Pengetahuan Alam, Univerrsitas Indonesia.

Kurnian Alfa, dkk. Identifikasi Kualitas Air Berdasarkan Nilai Resistivitas Air. Yogyakarta. Studi Kasus: Kali Gajahwong 